\title{
A Self-Position Recognition Method for Mobile Robots Based on Robot Calling by a User Using a Cellular Phone
}

\author{
Yasuo Saito Student Member (Soka University, ysaitou@soka.ac.jp) \\ Yongwoon Choi Non-member (Soka University, choi@t.soka.ac.jp) \\ Taketoshi Iyota Non-member (Soka University, iyota@t.soka.ac.jp) \\ Kazuhiro Watanabe Member (Soka University, watanabe@t.soka.ac.jp) \\ Yuzuru Kubota Non-member (Soka University, yuzuru@t.soka.ac.jp)
}

Keywords : cellular phone, robot calling and guiding, self-position recognition, map-matching, mobile robot

A service robot system consisting of a cellular phone available to common users and mobile robots has been investigated and developed for the purpose of supporting such human activities as the delivering documents and goods, guiding visitors and patrolling an indoor environment.

The system is composed of the cellular phone (a) of common users, one pair of a QR-code (b) and a barcode ( $\mathrm{g}$ ) to be pasted on the walls or doors expected, mobile robots (f) and management server (d) that controls the whole system, as shown in Fig.1.

A feature of the system is spontaneously able to recognize own location of the robot using the notion of Map-matching, by complying with the request called by a user with a cellular phone. This is possible because the robot's location can be corrected with a barcode of simple structure which is detected by a slit-ray sensor on the robot and a QR-code including location information to be read by a cellular phone. These codes also have the features that

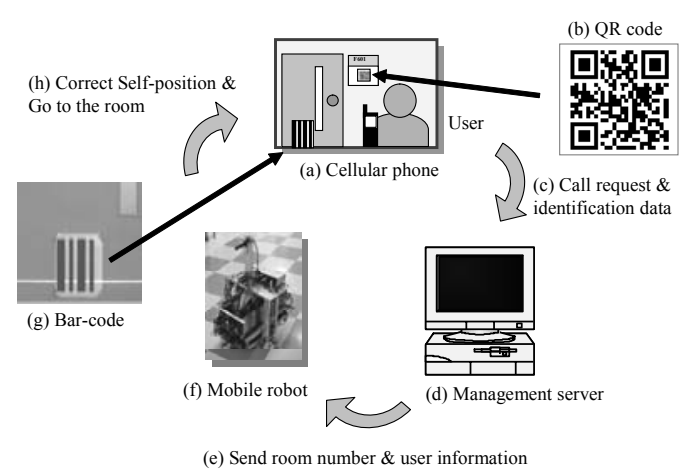

Fig. 1. System configuration for calling a robot and making it guide with a cellular phone

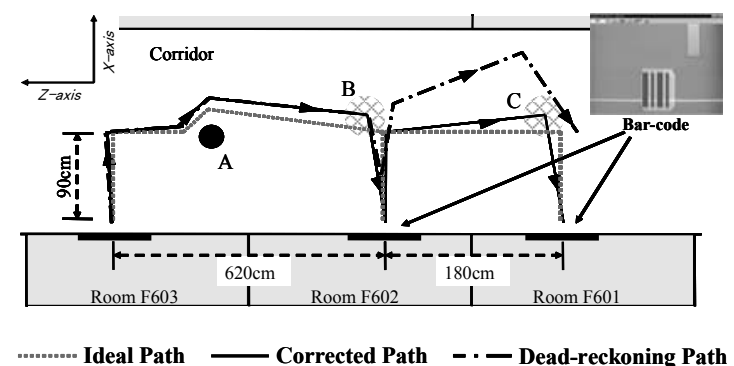

Fig. 2. Schematic of the running experiments and their trajectories performed in an indoor corridor

are simple to install them in the environment and easy to operate because users don't use an exclusive controller like keyboard on computers, but their own accustomed cellular phone for calling the robot.

Fig.2 shows the schematic trajectories of a robot run by the proposed method (solid line) and the dead reckoning (dash-dotted line) for an ideal path (broken line) in an actual corridor. The robot starts from roomF603 and moves a total of $1160(\mathrm{~cm})$ to the front of the door of roomF601 via roomF602 to avoid an obstacle A. By being corrected at $\mathrm{B}$ and $\mathrm{C}$ locations with the self-position method, we could confirm the measurement errors for $\mathrm{x}, \mathrm{z}$-axis are within $3.7,8.6(\mathrm{~cm})$, respectively.

From the repeated experiments performed with the robot in the indoor corridor, the proposed system was successfully evaluated in the measurement accuracy for some self-positions of the robot called and the reliability for practical navigation.

In addition, when the robot was arrived at a certain location, its behaviors to unexpected action of the user and the effect affected on it are discussed. 


\title{
携帯電話を用いたユーザによるロボット呼出しと それに付随した移動ロボットの自己位置認識
}

\author{
学生員 斎藤 康夫* 非会員 崔 龍雲* \\ 非会員 伊与田 健敏* 正 員 渡辺 一弘* \\ 非会員 久保田 譲*
}

\begin{abstract}
A Self-Position Recognition Method for Mobile Robots Based on Robot Calling by a User Using a Cellular Phone

Yasuo Saito*, Student Member, Yongwoon Choi*, Non-member, Taketoshi Iyota*, Non-member, Kazuhiro Watanabe*, Member, Yuzuru Kubota*, Non-member
\end{abstract}

\begin{abstract}
A service robot system consisting of a cellular phone available to common users and mobile robots has been investigated and developed for the purpose of supporting such human activities as the delivering documents and goods, guiding visitors and patrolling an indoor environment. The system has the feature that is spontaneously able to recognize the robot location on it using the notion of Map-matching, by complying with the request called by a user with a cellular phone. This is possible because the robot's location can be corrected with a barcode of simple structure which is detected by a slit-ray sensor on the robot and a QR-code including location information to be read by a cellular phone. These codes also have the features that are simple to install them in the environment and easy to operate because users don't use an exclusive controller like keyboard on computers, but their own accustomed cellular phone for calling the robot. From the repeated experiments performed with the robot in an indoor corridor, the proposed system was successfully evaluated in the measurement accuracy for some self-positions of the robot called and the reliability for practical navigation. In addition, when the robot was called at a certain location, its behaviors to unexpected action of the user and the effect affected on it are discussed.
\end{abstract}

キーワード：携帯電話, ロボット呼出・案内, 自己位置認識, マップマッチング, 移動ロボット

Keywords: cellular phone, robot calling and guiding, self-position recognition, map-matching, mobile robot

\section{1. はじめに}

近年，ロボットの要素技術の発達により，ロボットの利 用環境や利用形態も大きく様変わりしている。企業・大学等 数多くの機関で，人間と同じ環境で多彩な仕事を行うサー ビス提供型ロボットが提案・開発されている。本研究室で は屋内環境で用いるサービス提供型ロボットの実用化研究 を行っているが，このようなロボットシステムで必要とな る要素技術として以下の 2 つに着目する。

（1）ユーザの要求に応じてロボットを呼出すための技術

(2) 呼出し機能に付随したロボットの自己位置認識技術 まず，サービス提供型ロボットの場合，ロボット自身が

\footnotetext{
* 創価大学大学院工学研究科

广 192-8577 東京都八王子市丹木町 1-236

Graduate School of Engineering, Soka University

1-236 Tangi-cho, Hachioji, Tokyo 192-8577
}

自律的に作業を行うだけでなく，ユーザとコミュニケーショ ンを取りながら行う作業も数多く考えられる。ここで言う コミュニケーションとは, ユーザとロボットが自宅・オフィ ス間のような，まったく離れた場所でやり取りをする遠隔 操作のことではなく，ロボットとユーザが同じ建物内にお いて直接タスクを依頼すると言った，もっと近接したコミュ ニケーションのことである。

従来のロボットシステムにおける同一環境内でのユーザ・ ロボット間のコミュニケーション手法を見てみると, (1)ユー ザがロボットの近くまで移動してタッチパネルや音声認識 によって行う手法 ${ }^{(1)}$ ，また，(2)巡回中のロボットがカメラ などのセンサでユーザを発見した場合に音声などで行う手 法 ${ }^{(2)}$ がある。しかし, どちらの場合も, ユーザとロボット がお互いを確認できる位置にいないとコミュニケーション を取る事は困難である。いかに，ロボットにユーザをサポー トするための優れた技術が搭載してあったとしても，ユー 
ザがロボットとコミュニケーションを取りたいと思う時に， ロボットが身近にいないためにそのサポートを受けられな いというのであれば，その優れたロボットの技術も充分に 生かされているとは言えない。

そこで重要となるのが，ユーザが必要に応じてロボット を呼出すためのシステムである。従来もロボットと同一ネッ トワーク内に固定型の PC 端末や専用端末を設置したり，八 ンディタイプの専用端末を用いてロボットとコミュニケー ションをとる手法が提案されているが，ロボットを呼出す 状況は必ずしも PC 端末が常に整備された環境とは言えな い。また，このような端末をいたるところに設置するのは 環境構築の面から現実的ではない。加えて, ハンディタイ プの専用端末を用いる場合でも，その端末をはじめて利用 する人は，ロボットを呼出すために，まず，その端末の操 作方法を理解しなければならない。そこで本研究では，こ のロボットとのコミュニケーションに携帯電話を利用する 手法を考案した。この手法は，ロボットの呼出しや案内に ユーザが普段から使い慣れている自分の携帯電話を用いる ことで，いたるところに PC 端末を設置するといった煩雑 な環境整備や，ロボット呼出しのためだけに利用するコン トローラのような専用機器の導入，また，その場を初めて 訪れたユーザが理解するのに時間を要する難解な操作やガ イダンスの必要性がなく, 簡単にロボットを呼出すことを 可能にするものである。

次に，ユーザがロボットを呼出した時やそこから別の場 所へロボットに案内させる時に，ロボットが目的の場所ま で正確に到達できなければ意味がない。そこで, 自己位置 認識技術が不可欠となるが，本研究では，ロボットの呼出 し行為自体がユーザのタスク要求に加えて，自然のうちに 自己位置認識の 1 プロセスとなる，いわば，カーナビゲー ションの人間が介在したマップマッチング技術を組み入れ ている。

自己位置認識については, 従来までも様々な手法が提案 されているが，環境にランドマークを取り付ける手法 (3) (4) はシステムが大規模で環境に取り付けるセンサ自体に電源 装置が必要である。また, 環境内の特徵点をランドマーク として画像処理する手法 ${ }^{(5)}$ はあらかじめテンプレートを準 備し，複雑な処理を要してしまう。そこで筆者らは，こう した大規模な外的センサの設置などによる既存の環境の変 更を極力抑え，比較的簡便な処理で自己位置の認識が可能 な手法として，障害物回避用の赤外線スリット光センサと， そのセンサを利用して認識が可能で，かつ，構造が単純な バーコードを用いた自己位置認識手法を考案した。ランド マークとしてバーコードを用いる利点は，従来の手法に比 ベて，ドアに貼り付けるだけで，それ自体に電源装置等を 必要としないことや，バーコードのビット数を増やすこと で簡単に設置個所の増加が可能な点などが挙げられる。ま た，本研究のバーコードは，それを認識するための新たな 専用センサを準備する必要がなく, 赤外線スリット光セン サの特徴を活かすことができる。
そして，システムの複雑さや圥長さを決めるさらに重要 な点として，ランドマークを利用した自己位置認識の頻度 とタイミングが挙げられる。ランドマークの数が少なすぎ るとあるランドマークから次のランドマークに移動するま でに誤差が蓄積されてしまい，ランドマークの発見が行え なかったり, 誤認識の原因となったりする。逆にランドマー クの数が多すぎると環境が煩雑になり, 圥長な自己位置認 識を繰り返して, ロボットの処理負荷が増大する。そこで本 手法では, 必要最低限のランドマークで, 単純かつ精度の高 い自己位置認識を実現するために，屋外環境で最も一般的 な測位システムである GPS(Global Positioning System) の応用技術であるカーナビゲーションシステムで採用され ているマップマッチングという概念を取り入れた。

一般的に，カーナビゲーションシステムでは衛星局から の信号を定期的に受信することで，リアルタイムに自己位 置を認識することができる。最近では, 技術の発達により 誤差 $\pm 10[\mathrm{~m}]$ 程度の精度で測位が可能である。しかし, 測 位精度が向上した現在でも，位置認識には GPS からの位 置情報だけを利用しているのではなく，それと共に車載セ ンサを用いた推測航法, マップマッチングという技術を併 用して，GPS だけでは補いきれない誤差を補正している。 マップマッチングとは現在地が道路以外を指している場合, 「車は通常道路上を走っている」という前提に基づき，現在 地を近傍の道路上に修正するものである。これは自己位置 認識の全てをコンピュータ制御で行うのではなく，人間の 操作を信頼し，より精度の高い測位を実現するものである。 その根底にあるのは，機械制御に全てを任せるのではなく， その中で人間が担当できる部分は人間の操作を利用すると いう考えである。

カーナビゲーションシステムの場合は, 自動車と操縦者 が常に一緒に移動するため，走行中に生じる位置誤差をほ ぼリアルタイムに補正する事ができる。これは，いわば常 時マップマッチングと呼べるものであり，言い換えれば，人 間が移動体を常に監視する事ができるシステムである。そ れに対して，移動ロボットの場合は，その挙動を常に人間 に監視させる事は現実的ではない。しかし，常時には及ば ずとも，折々に人間の持つ確かな知識をロボットに活かす， いわば部分的マップマッチングが利用できれば望ましいと 考えられる。

そこで本手法では，ロボットの自己位置認識用バーコー ドとユーザがロボット呼出しに用いる QR コードを 1 セッ トとして各部屋のドアに設置し, ユーザがロボットを呼出 すという行為自体が自然のうちにロボットの自己位置認識 の第一段階も兼ねるという点で部分的マップマッチングを 取り入れている。このように，人間が折々に介在する事で, 人間の先見的知識，すなわち，ユーザが部屋を間違えるこ とは無いという前提を利用し, ランドマークの数を軽減さ せるなど，圥長な処理を行わないようにすることが可能と 考えている。さらに，その介在の程度は，第三者が常にロ ボットを遠隔監視しているような，ユーザに特別な作業を 
強いるものではなく, 単にロボットを呼出すという程度の, ユーザに負担にならないシステムとなっている。

本稿では上に述べたように，サービス提供型ロボットに 必要となる要素技術であるロボットの呼出し手法とそれに 付随した自己位置認識手法を提案し，この 2 つの手法をマッ プマッチングという概念を用いて統合する事で屋内環境で 利用可能なサービスロボットシステムを構築した。そして, 実際に屋内環境で行った実験をもとに検証したシステムの 有用性について述べる。

\section{2. 提案するシステムの概要}

本章では, 提案するシステムの構成およびユーザに呼出 されたロボットが自己位置認識を行い目的地に到着するま での手順について述べる。

まず，本システムの構成は，図 1 に示すように携帯電話 (a), QR コード (b), バーコード (g), ロボット (f), そし てそれらのシステム全体を管理するサーバコンピュータ $(\mathrm{d})$ からなる。管理用サーバ $(\mathrm{d})$ には，ユーザがロボットを用 いて呼出し・案内を必要とした時に携帯電話からアクセス するためのウェブページと, 次の 3.2 節で説明する携帯電 話の個体識別番号とユーザ情報を対応させたデータベース が用意されている。そして，QR コードとバーコードのセッ トは，あらかじめロボットを呼出す用途がありそうな場所 に貼り付けられている。ここで，QR コード (b)には，管 理用サーバ内のウェブページの URL と共に, 貼り付けら れた場所の位置座標が格納されている。また, バーコード （g）はロボットが目的地近傍まで到達したあとの自己位置 認識に用いる。携帯電話 $(\mathrm{a})$ は本システムのために特別に 用意したものではなく，QR コード読取機能が搭載されて いるユーザ個人のカメラ付き携帯電話である。ロボット (f) は座標が指定されれば，その場所まで移動することができ る自律型の移動ロボットである。

次に，システムの流れを順に説明する。ユーザが携帯電 話 (a)で QR コード (b) を撮像・認識する。そして携帯電話

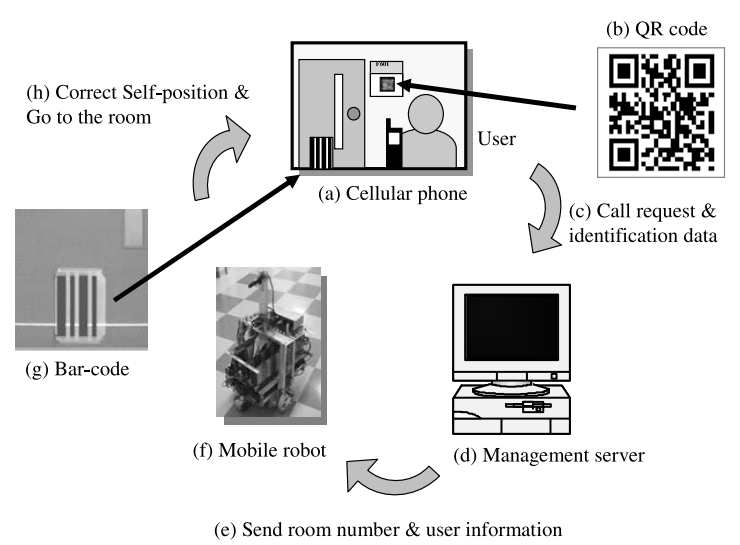

図 1 ロボット呼出し・案内システムの構成

Fig. 1. System configuration for calling a robot and making it guide with a cellular phone
の画面の指示に従って, 管理用サーバ (d) 内のウェブペー ジにアクセスすることで，管理用サーバにロボット (f) へ の呼出し要求を伝える。この時, その携帯電話の個体識別 番号も一緒に送信する (c)。呼出し要求を受けた管理用サー バはデータベースを参照し，その部屋の位置座標とユーザ 情報をロボットに送信する (e)。2つの情報を受け取ったロ ボットは命令に従って呼出された部屋付近まで移動し, 部 屋のドアに貼り付けてあるバーコード $(\mathrm{g})$ を用いて自己位 置認識を行い, 部屋の前まで移動する $(\mathrm{h})$ 。この時, 到着 したロボットはユーザに合わせて対応することができる。 具体的には，データベースにすでに登録されているユーザ からの呼出しであれば，ロボットに搭載されているスピー カで「こんにちは，○○さん」とそのユーザの名前を呼び, 未登録の来客の場合であれば「はじめまして，ゲストさん」 などのコミュニケーションを取ることができる。さらに, 現 在地から他の場所までの移動も携帯電話を用いてロボット に案内を促すことができるようになっている。

\section{3. 携帯電話を用いたロボット呼出し手法}

本システムでは従来手法と異なり, ロボットの呼出しに 専用端末ではなく携带電話を用いている。今までにも，携 帯電話とロボットを組み合わせた研究はいくつか提案され ており，代表的なものに，株式会社東芝で開発されたホー ムロボット「ApriAlpha」(6) や株式会社ゼットエムピーの 人型ロボット「nuvo」(7), 三洋電機株式会社の留守番ロボッ ト「番竜」(8) などがある。しかし, これらのロボットシス テムは携帯電話を使って, 離れた場所にいるロボットを遠 隔操作したり, テレビ電話機能付き携带電話であれば, ロ ボットの見ている画像をそのまま携帯電話に転送し，その 場の状況を監視したりするもので，携帯電話の特長とロボッ 卜技術を上手く連動させてはいるが，あくまで遠隔操作の ための手法であり, 我々の提案するロボットを呼出すため の手法ではない。

それに対して, 本手法では QR コード読取機能と個体識 別番号という携帯電話に搭載されている 2 つの機能に着目 し, ロボットの呼出しに携帯電話を利用する事で, 従来手 法よりも開発コストや操作性の面で優れた手法と言える。

〈3・1〉 QR コード読取機能 本システムで用いる QR コード読取機能は数年前から実用化され, 今後発売される 新型機種の携帯電話のほとんどに標準で搭載が期待される 機能である。そもそも, 近年, 高画素カメラ付き携帯電話 が普及したことにより，カメラを情報入力手段として利用 することが検討されてきた。その応用として，印刷された $\mathrm{QR}$ コードをカメラで撮影し, 画像認識によって QR コー ドに格納されている情報を抽出する技術が発達してきてい る。これにより, 名刺上に自分の電話番号やメールアドレ スなどの情報が埋め込まれた QR コードを印刷し, 携帯電 話への個人情報の登録を簡便化することや, 通信販売のカ

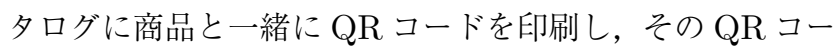
ドを読み取ることで携帯電話の通信機能を利用して通信販 
売のショップのウェブページにアクセスし，インターネッ 卜を介して商品の購入ができるサービスや, 電子クーポン など携帯電話と QR コードを連動させることで，実環境の メディアと電子メディアとの双方向コミュニケーションを 提案する企業も増えつつある ${ }^{(9)}$ 。

〈3・2〉 個体識別番号 本システムでは携帯電話の個 体識別番号とその携帯を所有しているユーザの名前などの 情報を関連付け，あらかじめデータベースに登録しておく ことで，ロボットがユーザとコミュニケーションを取る時 のユーザの識別に利用している。

個体識別番号とは，各携帯電話機が持つ機種や製造番号 等の固有の番号のことである。この番号は製造時に割り振 られるので，同じ番号の携帯電話は存在しない。電話番号 のように，機種変更を行った場合にも引き継げるものとは 違い，携帯電話が変わると個体識別番号も変更される。こ の個体識別番号を利用したサービスとしては，携帯電話か ら接続できるウェブサイトでのユーザ登録などに利用され， 個体識別番号をそのサイトに送信し，登録しておくことで， 次回の接続時からは煩雑なユーザ ID やパスワードを入力 する必要がなく，個体識別番号を送信するだけで登録ウエ ブサイトにアクセスすることができる。最近ではこのよう なサイトも増えてきている。

\section{4. ユーザとロボット間のコミュニケーション}

ロボットは環境内のネットワークに接続しており，環境 内のコンピュータからであればアクセスが可能である。し かし，携帯電話を用いてコミュニケーションを取る場合，た とえユーザがその環境内にいたとしても，直接環境内のネッ トワークにアクセスするわけではなく, 携帯電話から携帯 電話会社のサーバ，そして，ロボットの動作する環境内の サーバを経由してロボットにアクセスすることになる。

そこで，本手法でも環境内に設置されたシステム管理用 サーバに，外部からアクセスできるウェブページを作成し，

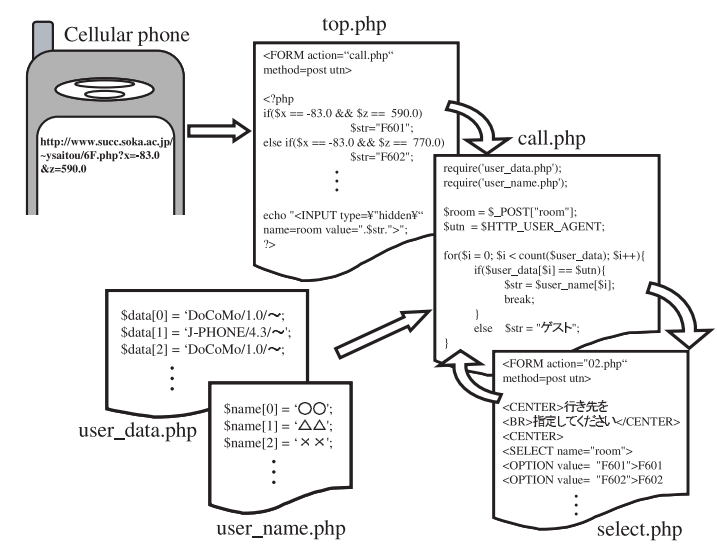

図 2 システム管理用サーバ内に作成した ウェブページの構成

Fig. 2. Web page configuration on the management server built for calling a robot and making it guide with a cellular phone
それを用いることでユーザとロボットのコミュニケーショ ンを行っている。ウェブページの作成には PHP(PHP: Hypertext Preprocessor) を用いる。これは JavaScriptのよ うに HTML ファイルの中に埋め込んで, 動的な Webペー ジを作成するためのオープンソースで提供されているサー バサイドスクリプト言語である。JavaScript の場合はクラ イアント側のブラウザで解釈されて動くため, ブラウザの 種類やバージョンといったクライアント環境で動作が大き く変ってしまうことがあるが, PHP はサーバサイドスクリ プト言語なので, クライアント側の環境に依存せずに動作 させることができる。また，CGIや Perl に比べて非常に 高速に実行でき，しかも負荷が少ないという特長もある。

図 2 に管理用サーバ上に作成したウェブページの 構成を示す。ウェブページは全部で 5 つのファイルか ら構成されており, 携带電話で $\mathrm{QR}$ コードを撮像す ると, 携带電話の画面にはトップページ (top.php) ヘ アクセスするための URL が表示される。例えば，座 標が $\mathrm{x}=-83.0, \mathrm{z}=590.0$ の位置の部屋に貼り付けてあ る QR コードを認識した場合, 携帯電話の画面には http://www.succ.soka.ac.jp/ysaitou/top.php? $\mathrm{x}=-83.0$

$\& z=590.0$ と表示される。この URL の top.php までの 部分は管理用サーバのアドレス, それ以降は各部屋の位置 座標を引数として送信している。また, top.php を作成する 際に, HTML の機能の一つである utn 属性を使用すること で，ユーザ所有の携带電話の個体識別番号を次の call.php に送信している。call.php ではウェブサーバ内の内部デー 夕を参照するための環境变数\$HTTP_USER_AGENTを 用いて, top.php から送信された個体識別番号を取得して いる。そして，各ユーザの携帯電話の個体識別番号が登録 してある user_data.php と各ユーザの名前が登録してある user_name.php を読み込み，ユーザと携帯電話の対応を確 認し，ロボットに移動命令と同時にユーザ情報を送信する。 select.php は目的地に到着したロボットに対して，ユーザ が新たな目的地への案内を希望する場合に，目的地番号を 指定するためのページである。 select.php で新たな目的地 の部屋番号を指定すると, 再び, call.phpに表示が切り替 わり，ロボットに移動命令とユーザ情報を送信する。

このようなウェブページを管理用サーバに用意すること で，ユーザは携帯電話を用いてロボットを呼出したり，案 内を指示したりするというコミュニケーションを取ること ができる。

\section{5. バーコードを用いた自己位置認識}

ロボットの自己位置認識には，できるだけ簡便で確実な 方法が望ましいため, 赤外線レーザスリット光レンジファ インダー（以下，赤外線スリット光センサと呼ぶ）と, その スリット光で認識が可能で, かつ, 構造が単純なバーコー ドを用いた手法を提案する。

$\langle\mathbf{5 \cdot 1}\rangle$ 赤外線スリット光センサ 従来から, 3 次元 データ取得や屋内ロボットの物体認識などに赤外線スリッ 
ト光センサのような赤外線系のセンサを用いた研究は数多 く報告されている。赤外線系センサを用いている理由は，機 構的に簡便で対象物のエッジ検出能力に優れているためで ある。本稿で提案するシステムでは，ロボットの動作環境 はオフイスの廊下のような比較的狭く障害物の存在する場 所を想定しているため，その環境認識に用いるセンサには 対象物のエッジ検出能力に優れた赤外線スリット光センサ をロボットに実装した。赤外線スリット光センサは，赤外 線投光器とカメラから構成される。赤外線投光器には赤外 線半導体レーザを用い，その赤外光をシリンドリカルレン ズでスリット状にしている。このセンサを用いると，対象 物のエッジのみならず，例えば，カメラ画像面の投影像が 棈円弧であれば実環境での円柱の存在を示し，その半径と 中心座標が求まる。また，直線の場合は実空間での柱や壁 などの平面を示し，直線までの距離とその傾きを求めるこ とができる ${ }^{(10)}$ 。

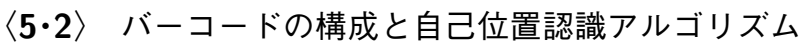
本手法で用いるバーコードは，縦 $297[\mathrm{~mm}] \times$ 横 $210[\mathrm{~mm}]$ の白色の台紙に黒色テープを貼り付けたもので，このバー コードをドアに貼り付けた様子を図 3(a) に示す。バーコー ド上の白い横ラインは赤外線スリット光センサから照射さ れる赤外光で，それを赤外線スリット光センサの赤外線透 過フィルタ付カメラで撮像した画像が図 3(b) である。同図

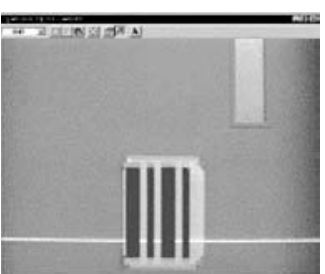

(a)

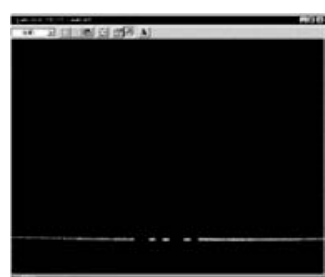

(b)
図 3 ドアに貼られたバーコードの画像 (a) と それを赤外線透過フィル夕付きカメラで 撮像した画像 (b)

Fig. 3. A visible image(a) and its filtered image(b) of a bar-code posted on a door

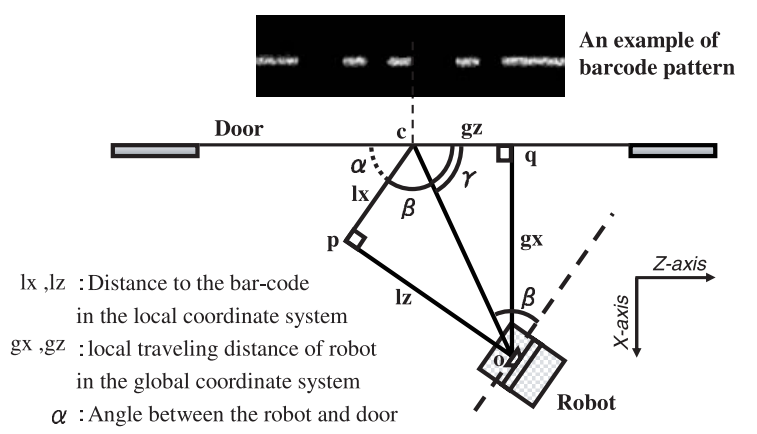

図 4 バーコードを用いたロボットの

自己位置認識手法

Fig. 4. A method of finding the distance to guide a robot from the current location to the front of the bar-code
のバーコードは, 白色バーの部分ではスリット光が多方向 に散乱するため，カメラで撮像できる。一方，黑色バーの 部分は光を反射する素材であり, また，スリット光投光器 の角度がカメラの光軸に対して下向きに取り付けらている ため，赤外光がカメラとは別の方向に反射し，カメラには 撮像されない。その結果, 眓のように途中でいくつかに分 断されたスリット光の画像が得られる。

実験に用いたバーコードは 10 本のバーで構成され，1 つのバーの太さは $2[\mathrm{~cm}]$ である。この太さは, 幅 $240[\mathrm{~cm}]$ の廊下の中心を走行するロボットが自己位置認識を行う場 合，それまでに累積された走行時のずれが，ドアに貼り付 けたバーコードの正面から $120[\mathrm{~cm}]$ の地点を中心とする半 径 $30[\mathrm{~cm}]$ 以内に納まると仮定した場合に，その範囲内で認 識可能な太さを実験的に求めて設定した。ここでは, 黒色 バーに 0 , 白色バーに 1 を対応させている。10本のバーの うち最初の 5 本をスタートビットと呼び，これは常に 00101 を表現している。このスタートビットは，ロボットの走行 環境内にバーコードと類似した模様がある場合にそれらの 模様とバーコードを識別するためのもので，これによって バーコードの認識率を向上させることができる。次に，七 ンサがスタートビットから, 撮像画像中にバーコードを発 見すると, 後半の 5 ビットの認識に移る。後半の 5 ビット はデータビットと呼び，このビットの值によって部屋番号 を識別する。図 3 に示すバーコードの例では 0010100101 で，5号室を表わしている。

バーコードを貼り付ける位置はカメラの視野角を考慮に 入れ, 床面から $18[\mathrm{~cm}]$ の高さで, 図 4 の $\mathrm{c}$ 点を通る点線で 示すようにちょうどスタートビットとデータビットの境界 線がドアの中心になるようにする。ロボットはあらかじめ 実験環境のグローバル座標系での各ドアの位置座標を保持 しているので，デッドレコニングによって目的のドア付近 まで移動する。そして, ロボットは目的のドアの前に到達 すると一旦停止し, 赤外線スリット光センサを用いてバー コードの探索に移る。もし，1回目の撮像でバーコードが 赤外線スリット光センサのカメラの視野角に入らなければ, その場で左右に旋回しながらバーコードの探索を続ける。 ロボットはドアのバーコードを検出すると，次に述べる方 法で自己位置を補正するための移動距離を導出する。

まず，図 4 に示すように，赤外線スリット光センサの原理 を用いて，ロボットからバーコードまでの距離 $l x, l z[\mathrm{~cm}]$ と，ロボットとバーコードのなす角度 $\alpha[\mathrm{rad}]$ を得る。この $l x, l z[\mathrm{~cm}]$ からロボットとドアの中心との直線距離 $c o[\mathrm{~cm}]$, ロボットと $c o[\mathrm{~cm}]$ とのなす角度 $\beta[\mathrm{rad}]$ が求まる。次に, $\alpha[\mathrm{rad}]$ と $\beta[\mathrm{rad}]$ から $c o[\mathrm{~cm}]$ とドアとの角度 $\gamma[\mathrm{rad}]$ を求 め, 最終的に (1) 式より実験環境のグローバル座標系での ロボットの位置 $g x, g z[\mathrm{~cm}]$ が求まる。この $g x, g z[\mathrm{~cm}]$ と ドアの位置座標との差を計算することで，ロボットはそれ までのデッドレコニングによって蓄積された位置や姿勢の 誤差を補正し，ドアの中心に正対する位置に移動すること が可能となる。 
$g x=c o \cdot \sin \gamma, \quad g z=c o \cdot \cos \gamma \cdots \cdots \cdots \cdots(1)$

ここで,

$c o=\sqrt{l x^{2}+l z^{2}}, \beta=\tan ^{-1} \frac{l z}{l x}, \gamma=\pi-(\alpha+\beta)$

\section{6. 実 験}

本稿で提案するシステムの有用性と再現性を確認するた め, 実際に屋内環境で移動型ロボットを用いて動作実験を 行った。

〈6・1〉 ロボットのシステム構成＼cjkstart本実験で使用する ロボットの外観を図 5 に示す。ロボットは市販の PC 汎用 ボードを用いて構成されており，メンテナンス，バージョ ンアップが簡単に行えるよう設計されている。ロボットの 前部には Celelon850[MHz] の CPU を搭載した CPU ボー ドや無線 LAN カード等を含む PC 沉用ボードが，後部に はスピーカーが搭載されている。また，外界センサとして ロボット上部には 5.1 節で説明した赤外線スリット光セン サが搭載されており，これを用いて，ロボットは自己位置 認識や障害物回避 (11) を行い, 自律的に指定された場所ま で走行することが可能である。スピーカーはユーザとの音 声会話に用い，ユーザに対して指示を促すコミュニケーショ ンに用いる。通常, ユーザが携帯電話を用いて呼出し要求 を行った場合，ロボットは本研究で提案する赤外線スリッ ト光センサとバーコードを用いて自己位置認識を行い，指 定された部屋の前まで移動し，ユーザとのコミュニケーショ ンを取る。

$\langle\boldsymbol{6} \cdot 2\rangle$ 自己位置認識精度の計測実験 まず，ロボット がユーザから呼出された場合を想定し, その自律性を確認 するために，簡単な障害物のある環境で走行時の自己位置 認識精度の計測を行った。困 6 に実験環境と走行軌跡のモ デル図を示す。実験環境は本学研究棟の廊下 (幅 $240[\mathrm{~cm}]$ ) とし, F601, F602, F603 の各部屋のドアには 5.2 節で説 明したバーコードが貼り付けてある。図中の黒丸 A は円柱 型の障害物を表し，その半径は $11[\mathrm{~cm}]$ である。今回の走 行経路は F603 のドアの前をスタート地点とし, 障害物 $\mathrm{A}$ を回避し，F602 のドアの前で一旦停止し，続けて F601の ドアの前まで移動するもので，走行距離は X 軸方向， Z 軸 方向合わせて $1160[\mathrm{~cm}]$ である。再現性を確認するために, 同様の条件で 10 回走行させた。

もし，ロボットが走行中にまったくずれを生じなければ， 図中の点線で示すように理想的な経路を描き，F601のド アの前まで走行する。しかし，ロボットはデッドレコニン グで廊下を走行するため, 図中の一点鎖線で示すように走 行経路にずれが生じてしまい，正確に目的地点に到達する ことができない。そこで，デッドレコニングによる自己位 置のずれが大きくなる前に，本手法を用いて自己位置認識 を行っている。具体的にはロボットの走行時のずれが理想 的な経路を中心として半径 $30[\mathrm{~cm}]$ を超える前に，そのずれ を各部屋の前のグレーの部分 $\mathrm{B}, \mathrm{C}$ で補正することで，図

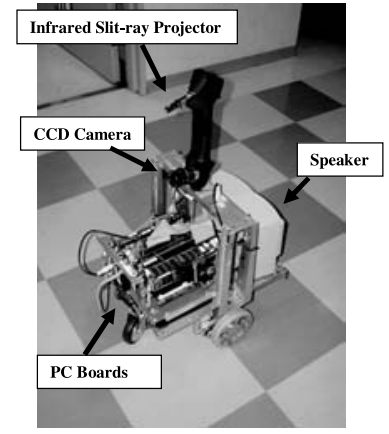

図 5 実験用移動ロボットの概観

Fig. 5. Overview of the robot used in running experiments

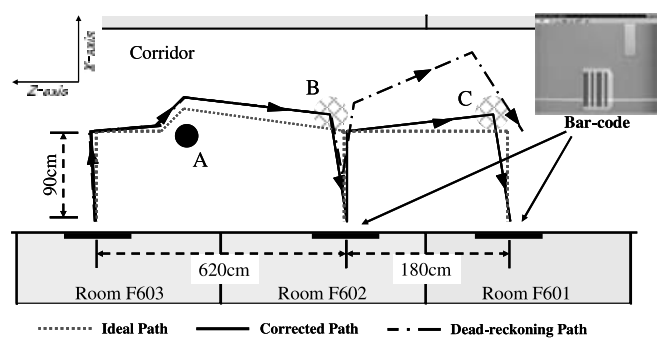

図 6 廊下で行った実験の走行軌跡のモデル図

Fig. 6. Schematic of the running experiments and their trajectories performed in an indoor corridor

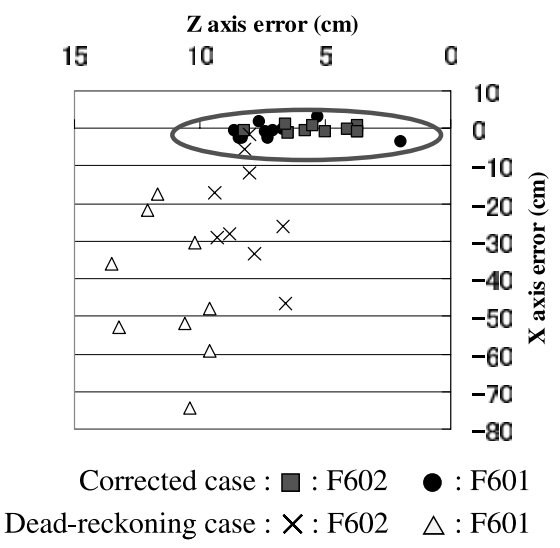

図 7 自己位置認識の計測精度

Fig. 7. Location errors of the robot actually runned for the ideal location

中の実線で示す経路のように正確に目的の部屋に到達させ ることが可能である。

図 7 はF602, F601の前の理想的な到達位置に対し, 実 際の走行時における $X$ 軸， $Z$ 軸方向のずれをまとめて表 示したものである。図中の $\times, \triangle 1 F 603$ のドアの前から F602, F601のドアの前までデッドレコニングで走行した 場合の到達位置の誤差を示している。ロボットは連続的に F602 から F601 へ向かうので，それに伴い, 走行時のずれ も徐々に増加し, F601のドアの前では F602 のドアの前に 比べ，さらに位置誤差が大きくなっていることがわかる。 
それに対し，本手法を用いた場合は，F602のドアの前の位 置誤差

), F601 のドアの前の位置誤差

共に, 楕

円で囲まれた範囲に収まっており，明らかに位置誤差が小 さくなっていることが確認できた。また，最大位置誤差を 比較しても，デッドレコニングによる走行の場合， $X$ 軸で $74.5[\mathrm{~cm}], Z$ 軸で $13.5[\mathrm{~cm}]$ の誤差を生じているのに対し, 本手法を用いた場合は， $X$ 軸， $Z$ 軸それぞれ，3.7, $8.6[\mathrm{~cm}]$ まで改善されていることが確認できた。

$\langle 6 \cdot 3\rangle$ 口ボット呼出し・案内実験 次に, ロボットが ユーザからの呼出しに応じて目的地まで移動し, 正確な自 己位置認識を行えるかどうかを確認するための呼出し・案内 実験を行った。実験はユーザ個人の携帯電話を用いて，待機 中のロボットを F601 研究室に呼出し，そこから隣の F602 研究室へ案内させるというもので，事前に登録されている ユーザ (user1, user2) とゲストの 3 人の場合をそれぞれ 3 回ずつ, 計 9 回行った。図 $8(\mathrm{a}) \sim(\mathrm{h})$ がその実験の様子で ある。各研究室のルームプレートには，その部屋情報が格 納された QR コードが貼り付けられている。(a) はF601 研 究室のルームプレートに QR コードが貼られている様子で ある。写真からもわかるように，QR コードは携帯電話で 撮像できれば良いので，普通紙に印刷したもので，大きさ も $2.7 \times 2.7[\mathrm{~cm}]$ と非常にコンパクトである。

実験の流れについては，まず (b) に示すように user1が， F601 研究室の前で自分の携帯電話を用いて，その $\mathrm{QR} コ ー$ ドを撮像する。その後，携带電話の指示に従ってロボット呼 出し用ウェブページにアクセスすると，部屋情報と同時に その携帯電話の個体識別番号が管理用サーバを経由してロ ボットに送信される (docomo 社の携帯電話の場合は送信・ 非送信を選択可能)。その信号を受信したロボットは,「わか りました。F601に向かいます」と発声し，移動を開始する (c)。それと同時に, user1 の携带電話画面にはロボットの 状態がわかるように,「ロボットが F 601 に向かいます」と 表示される。さらにロボットの移動中は, user1 の携帯電 話画面に (d) のようにロボットの到着までの経過が表示さ れる。ロボットは呼び出された研究室付近まで到着すると, (e)のようにドアに貼り付けられているバーコードを用い て自己位置認識を行い，ドアの前に正確に到着する。そし て，管理用サーバから送信された個体識別番号で user1を 識別し，「こんにちは。user1 さんですね。携帯電話で行き 先を指定してください。」と user1の名前を呼び上げ，次の 指示を待つ。そこで，(f) のように user1 が携帯電話の画面 でF602 研究室を指定すると，ロボットは「わかりました。 F602 向かいます」と発声し，移動を開始する。(g), (h) はその後，ロボットが user1 を F602 研究室まで案内して いる様子である。

9 回行った走行実験の結果，ユーザの誤認識，部屋の誤認 識等をすることなく正確に目的の研究室まで走行し，ユー ザに合わせた音声会話も実行することができ，本システム の再現性，実用性を確認することができた。

$\langle\mathbf{6} \cdot \mathbf{4}\rangle$ 長距離走行実験 最後に，本システムの走行

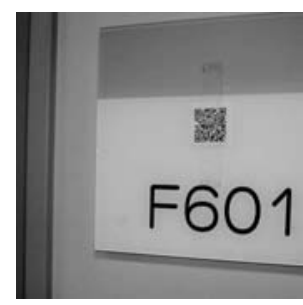

(a)

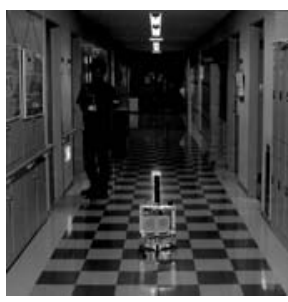

(c)

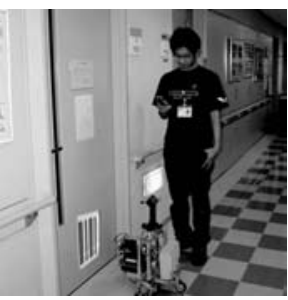

(e)

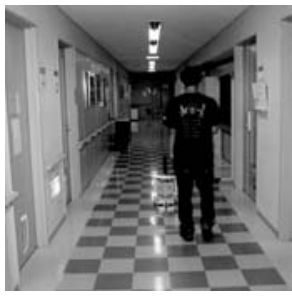

(g)

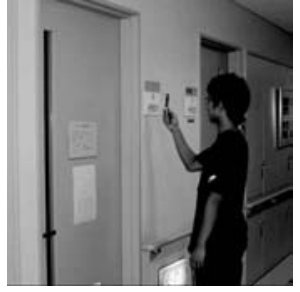

(b)

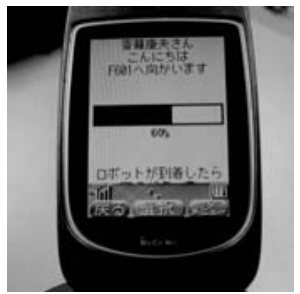

(d)

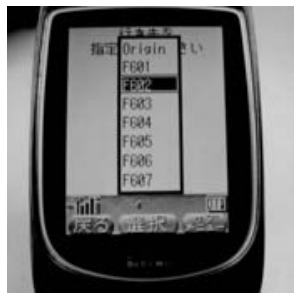

(f)

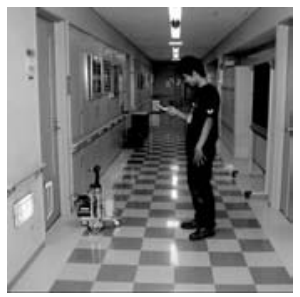

(h)
図 8 ロボット呼出し・案内システムの 運用実験の様子

Fig. 8. Scenes to show the experiment state from calling the robot to guiding a user

時における安定性，再現性を確認するために，障害物の数 とロボットの走行距離を延ばし，より実用に近い状態での 長距離走行実験を行った。この実験も上記 $2 つ の$ 実験と同 じ環境で行い，障害物 A (半径 $12[\mathrm{~cm}]$ の円柱)，B，C（幅 $35[\mathrm{~cm}]$, 奥行 $22[\mathrm{~cm}]$ の角柱）を図 9 のように配置した。な お, 図中の各部屋の位置を示す座標の単位はすべて $[\mathrm{cm}]$ で ある。ユーザが F602 の前でロボットを呼出し，Start 地点 にいるロボットが，障害物を回避しながら F602 の前まで 到着する。その後，ユーザの指示に従って，F603，F608 を経由し F609 まで $3410[\mathrm{~cm}]$ の距離を案内走行させると いう実験を 5 回繰り返し, 走行時の安定性と再現性を確か めた。その中の 1 回分の実験結果の軌跡を図 9 に示す。図 中の各部屋番号の右側の数值は Start 地点を原点とした時 の, 各部屋の位置座標 $(\mathrm{x}, \mathrm{z})$ である。ユーザから呼び出さ れたロボットは障害物を回避しながら, 各経由先の部屋の 


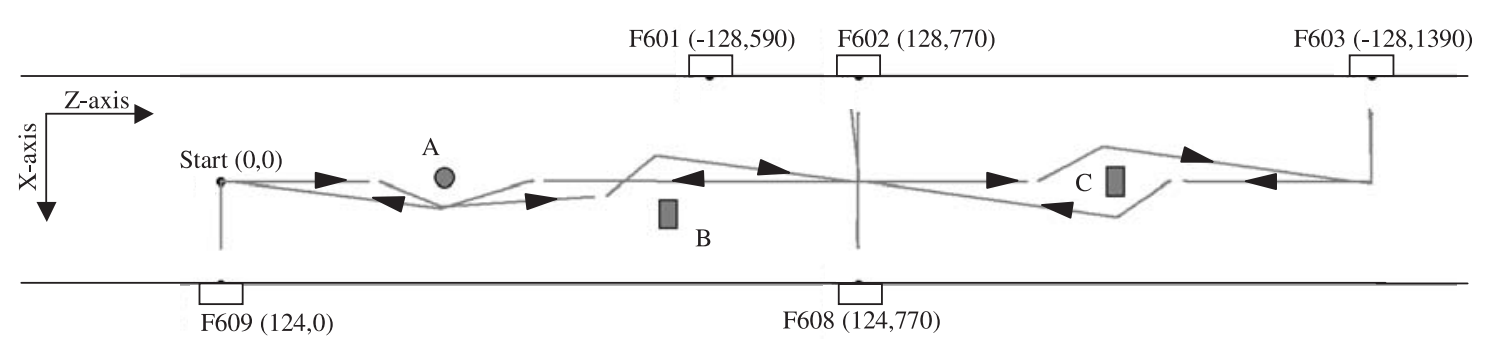

図 9 安定性と再現性を確認するために行った長距離走行実験で得られた走行軌跡

Fig. 9. A trajectory of running experiments for ensuring the stability and repeatability in long distance

前でドアに貼り付けてあるバーコードを用いて自己位置を 認識し，走行時の誤差を蓄積することなく，正確に最終目 的地である F609 に到達することができた。また，その都 度，ユーザとコミュニケーションを取りながら案内夕スク を実行することもできた。この結果から，本研究で提案す るシステムが長距離走行の場合でも安定して動作すること が確認でき，5回ともにほぼ同様の軌跡を描いたことから 再現性も確認することができた。さらに距離が延びた場合 も，ロボットの走行誤差が $30[\mathrm{~cm}]$ を超えない適度な間隔で 自己位置認識を行いながら走行することで連続的な走行が 可能である。

\section{7. ユーザの呼出し行為がロボットにもたらす効果}

本稿ではユーザがロボットを手軽に呼出す事ができ，そ のロボットが正確にユーザの場所まで移動し, 指示に応じ てユーザを案内するための手法について論じてきた。

この時, ロボットを呼出すユーザの状況は様々考えられ る。例えば，ロボットを必要としたユーザが，携帯電話を用 いてロボットを呼出したが，何らかの事情によりその場か ら離れる必要が出てきた場合, ユーザがロボットに期待す る事として，その場所で待機していてもらうか, 再度ユー ザの場所まで移動してもらうか, 少なくともこの 2 つの選 択肢が考えられる。そこで，本システムではロボットが到 着した際に，その場にユーザがいなければ，呼出したユー ザの携帯電話にメールを送信し, その場所に待機するのか, ユーザの場所まで移動するのかの指示を受けられる機能を 搭載した。これによって，ロボットはユーザの状態によっ て作業を中断することなく，ユーザの期待に応えることが 可能となる。

さらに，ユーザがロボットを呼出すことはロボットにとっ ても大きな効果をもたらす。本手法では，マップマッチング の概念を取り入れることで，ユーザがロボットを呼出すと いう行動をロボットの自己位置認識に関連付けている。そ のため, 仮に, 何らかの理由で, ロボットが呼出したユーザ と連絡が取れない状況に陷っても，ロボットにとっては夕 スクが達成されなかったわけではなく, 自己位置補正とい うロボットにとって非常に重要なタスクを達成する事がで きるわけである。つまり, カーナビゲーションシステムで,
車が角を何度も曲がる事によって自己位置を補正していく ように，本手法のロボットもユーザに呼び出されることに よって, 自己位置認識の精度を向上する事が可能となる。

\section{8. おわりに}

本稿では，近年注目されてきている人間と共存する環境 でのサービス提供型ロボットについて，まず初めに，必要 となる 2 つの要素技術について取り上げた。

1 つ目は, 従来なかなか提案されていなかった同一環境 内でロボットを自分の位置まで呼出すための手法である。 これについては従来手法のように呼出しのための専用端末 を用いるのではなく, 一般的に普及している携帯電話を用

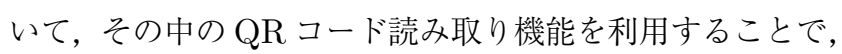
環境構築やユーザの操作性の簡便さを向上させることがで きた。また，個体識別番号を用いることで，ユーザ認証も 行うことができ, 今後のセキュリティー面での安全性の向 上にも発展させることが可能である。

2 つ目は, ロボットの呼出し機能に, 自然のうちに組み 込まれた自己位置認識手法である。この自己位置認識につ いては赤外線スリット光センサとバーコードと言う, とて も簡便なシステム構成でありながら, 屋内環境を移動する ロボットに必要不可欠な自己位置認識機能を付与すること ができた。これによって, 従来手法に比べても, 環境構築 のコストや簡便さ, アルゴリズムの単純さ, 汎用性の高さ などにおいて優れた手法を提案する事ができた。

そして，これら 2 つ技術を，カーナビゲーションシス テムでも利用されているマップマッチングという概念を取 り入れることで融合し, ユーザによるロボット呼出しとロ ボットの自己位置認識という 2 つ技術を関連付けた。こ れによって, 必要最低限のランドマークで正確な走行を行 うことができ，実機実験によりシステムの有用性と実用性 を確認する事ができた。合わせて, ロボットを呼出したユー ザの行動について検討し, 本システムがユーザの不慮の行 動に対しても柔軟に対応しながら, かつ, ロボットの自己 位置認識タスクが実現されている事を示した。

今後は, 外部のユーザからのアクセスに対して, 呼出し 目的の確認を行えるような機能を追加し，セキュリティー や個人認証の面でも安全性を追加したり, また，指定した 
時間に指定した場所に呼出せる時間指定機能などを追加す ることで，用途に応じた拡張が可能である。

\section{謝 辞}

本研究の一部は，文部科学省私立大学学術研究高度化推 進事業「私立大学社会連携研究推進事業」(平成 18 年度 平成 22 年度): 研究課題「測位/光神経複合センサノードに よるユビキタス・モニタリング・ネットワークの開発とその 産業応用への展開」の一環として実施したものである。記 して，厚く御礼申し上げます。

(平成 18 年 4 月 11 日受付，平成 18 年 10 月 24 日再受付)

\section{文献}

(1) Y. Shimosasa: "Business of Guard Robot", RSJ, Vol.20 No.7, pp.692-695 (2002-10) (in Japanese)

下笹洋一：「警備ロボットビジネス」，日本ロボット学会誌，Vol.20, No.7, pp.692-695 (2002-10)

(2) Y. Fujita: "Personal Robot Development in NEC", RSJ, Vol.20, No.7, pp.676-679 (2002-10) (in Japanese) 藤田善弘：「NEC におけるパーソナルロボットの開発」，日本ロボッ 卜学会誌, Vol.20, No.7, pp.676-679 (2002-10)

(3) M. Iwata, H. Takahashi, K. Sasaki, and M. Takano: "Positioning System for Mobile Robot using LED Marks", JSPE, Vol.61, No.11, pp.1579-1583 (1995-11) (in Japanese) 岩田宗之·高橋英男 ·佐々木健・高野政晴:「LED 灯台を用いた移動 ロボット用位置姿勢検出システム」, 精密工学会誌, Vol.61, No.11, pp.1579-1583 (1995-11)

(4) H. Seki, Y. Tanaka, M. Takano, and K. Sasaki: "Positioning System for a Mobile Robot Using Ultrasonic Lighthouses", 14th Conf. of RSJ, Vol.2, pp.511-512 (1996-11) (in Japanese) 関 啓明・田中康夫・高野政晴・佐々木健：「超音波灯台を用いた移 動ロボットの位置検出システムの開発」, 第 14 回日本ロボット学会 学術講演会予稿集，Vol.2, pp.511-512 (1996-11)

(5) H. Kami, Y. Matsumoto, M. Imai, and T. Ogasawara: "Indoor Navigation Based on Ceiling Images", 18th Conf. of RSJ, Vol.1, pp.331-332 (2000-9) (in Japanese) 紙 弘和・松本吉央・今井正和・小笠原司：「天井画像列を用いた屋 内ナビゲーション」, 第 18 回日本ロボット学会学術講演会予稿集, Vol.1, pp.331-332 (2000-9)

（6）「東芝プレリリース」，http://www.toshiba.co.jp/about/press/ 2003_03/pr_j2001.htm

(7) 「CNET Japan」, http://japan.cnet.com/news/tech/story/0, 2000047674,20064628,00.htm

(8) 「SANYO ニューリリース」, http://www.sanyo.co.jp/koho/ hypertext4/0404news-j/0405-1.html

（9）辻本優一：「携帯電話バーコードリーダーの現状と可能性」，月刊 自動認識, Vol.17, No.12, pp.48-51, 日本工業出版 (2004-10)

(10) Y. Choi, H. Morinaga, Y. Kubota, and K. Watanabe: "Laser Sheet Beam Projector to Recognize the Complex Surfaces of Curvature and Plane", Review of LE, Vol.27, No.6, pp.421425 (1999-6) (in Japanese)

崔 龍雲・森永裕之・久保田譲・渡辺一弘：「レーザーシートビー ム光投影法を用いた曲面平面混在環境の認識」, レーザー学会誌, Vol.27, No.6, pp.421-425 (1999-6)

(11) M. Morishima, Y. Saito, Y. Choi, T. Iyota, K. Watanabe, and Y. Kubota: "Navigation for mobile robot considering obstacle shape using slit-ray sensor", 2001 JSME conf. on Robotics and Mechatronics, 1A1-N5 (2001-6) (in Japanese)

森島三惠 · 斎藤康夫 · 崔 龍雲, 伊与田健敏 $\cdot$ 渡辺一弘 · 久保田譲 「スリット光センサを用いた障害物の外形認識による移動ロボットの 走行制御」，日本機会学会ロボティクス・メカトロニクス講演会'01 講演論文集，1A1-N5 (2001-6)
(学生員) 1975 年 3 月 3 日生。1997 年創価大学 工学部情報システム学科卒業。現在, 同大学院工 学研究科情報システム学専攻博士課程在学中。日 本ロボット学会会員。

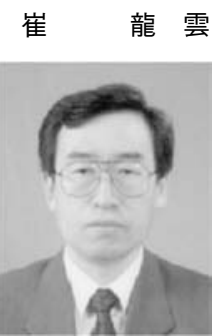

(非会員) 1961 年 2 月 25 日生。 1983 年韓国中 央大学工学部電子計算学科卒業。95 年神戸大学 大学院自然科学研究科博士課程システム科学専攻 修了。現在, 創価大学工学部助教授。ロボットビ ジョン, 自律移動ロボットの研究に従事。日本ロ ボット学会, 計測自動制御学会, 電子情報通信学 会等の会員。(工学博士)

伊与田 健 敏 (非会員) 1964 年 3 月 4 日生。1986 年東北大

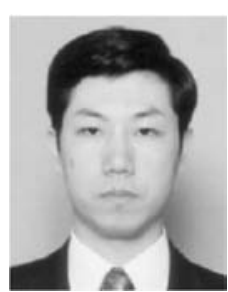
学工学部応用物理学科卒業。92 年同大学院工学 研究科応用物理学専攻修了。現在, 創価大学工学 部講師。画像による環境認識，超音波による距離 計測と測位システム等の研究に従事。日本物理学 会，電子情報通信学会各会員。(工学博士)

渡 辺 - 弘 (正員) 1953 年 8 月 13 日生。 1976 年慶應義塾

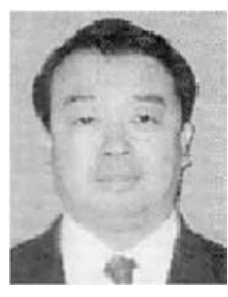
大学工学部電気工学科卒業。 81 年同大学院工学 研究科電気工学専攻博士課程修了。現在, 創価大 学工学部教授。レーザの光情報装置への応用, 光 ファイバセンサ，自律移動ロボットの自己位置認 識システム等の研究に従事。計測自動制御学会, 日本ロボット学会, 応用物理学会, 可視化情報学 会等会員。(工学博士)

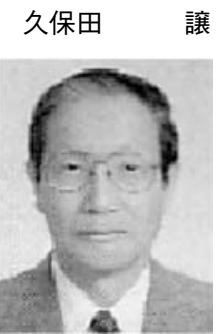

(非会員) 1939 年 7 月 11 日生。1963 年室蘭工 業大学工学部機械工学科卒業。6 8 年北海道大学 大学院工学研究科精密工学専攻博士課程単位取得 退学, 同年室蘭工業大学講師。現在, 創価大学工 学部教授。制御, ロボット挙動等の研究に従事。 計測自動制御学会, 日本機械学会, 日本ロボット 学会等会員。(工学博士) 